\title{
Characterisation of protected denomination of origin cheeses: relationships between sensory texture and instrumental data
}

\author{
Yolande Noëla*, Ylva Ardöb, Sylvie Pochet ${ }^{\mathrm{a}}$, Anthony Hunter ${ }^{\mathrm{c}}$, \\ Pierre Lavanchyd, Werner Luginbühld ${ }^{\mathrm{d}}$, Dominique Le Bars ${ }^{\mathrm{e}}$, \\ Anna Polychroniadouf, Luisa Pellegrinog
}

${ }^{\text {a }}$ Station de recherches en technologie et analyses laitières, Inra, BP 89, 39801 Poligny, France

${ }^{b}$ Dairy Technology, Department of Dairy and Food Science, The Royal Veterinary and Agricultural University, Rolighedsvej 30, DK 1958 Frederiksberg, Denmark

${ }^{\mathrm{c}}$ Biomathematics and Statistics Scotland (BioSS), University of Edinburgh, Edinburgh, EH9 3JZ, Scotland, UK

${ }^{\text {d }}$ Federal Dairy Research Institute, FAM, Liebefeld, CH-3097 Liebefeld-Bern, Switzerland

e Station de recherches laitières, Inra, Domaine de Vilvert, F-78352 Jouy-en-Josas, France

${ }^{\mathrm{f}}$ Dairy Technology, Aristoteles University of Thessaloniki, P.O. Box 265, GR-54006 Thessaloniki, Greece

g Dipartimento di Scienze e Technologie Alimentari e Microbiologiche, Sezione Industrie Agrarie, Università degli Studi di Milano, Via Celoria 2, I-20133 Milan, Italy

(Received 12 December 1996; accepted 20 April 1998)

\begin{abstract}
Relationships between sensory and instrumental measurements of cheese texture have been explored through an interlaboratory experiment in the framework of a European FLAIR programme (SENS, Concerted Action no. 2, contract AGRF 025). Ten very different samples of each of the two cheese varieties, Appenzeller, a Swiss semi-hard cheese, and Parmigiano Reggiano, an Italian very hard cheese, were analysed using biochemical, rheological and sensory methods. The relational study is one of the first using harmonised methods. Results have shown that sensory data can be related to instrumental data. Partial least square regression appears useful to relate sensory textural properties from instrumental data. The approach is recommended for similar investigations of other cheese varieties. () Inra/Elsevier, Paris.
\end{abstract}

texture cheese / relational study / sensory / biochemistry / rheology

Résumé - Caractérisation des fromages « d'appellation d'origine protégée » : relations entre descripteurs sensoriels de la texture et données instrumentales. Les relations entre les critères ins-

* Correspondence and reprints. E-mail: noel@poligny.inra.fr 
trumentaux et sensoriels de la texture ont été explorées dans un essai interlaboratoire dans le cadre d'un programme européen Flair (Sens, Action concertée n ${ }^{\circ} 2$, contrat AGRF 025). Dix échantillons très différents de deux variétés de fromages, l'Appenzeller, un fromage suisse à pâte semi-dure, et le Parmigiano Reggiano, un fromage italien à pâte très dure, ont été analysés avec des méthodes biochimiques, rhéologique et sensorielle. Cette étude relationnelle est l'une des premières basée sur des méthodes harmonisées. Les résultats ont montré que les données sensiorielles peuvent être reliées aux données instrumentales. Une méthode statistique de régression multidimensionnelle (PLS) apparaît pertinente pour relier les propriétés sensorielles de texture aux données instrumentales. Cette approche est recommandée pour des investigations semblables sur d'autres variétés de fromages. (c) Inra/Elsevier, Paris.

\section{texture / fromage / étude relationnelle / analyse sensorielle / biochimie / rhéologie}

\section{INTRODUCTION}

There is an increasing need for objective characterisation of cheeses in order to define and control quality. Sensory analysis is widely used by professionals in order to assess food quality and to predict consumer acceptance. But sensory evaluations require a large panel of trained assessors, are time consuming and costly, and so limited to a restricted number of samples. From this point of view, sensory analysis could be advantageously replaced by instrumental measurements for large-scale quality controls as far as it has been demonstrated that sensory characteristics can be satisfactorily predicted $[39,40]$. Nevertheless, instrumental and sensory methods should be developed or optimised in a way which will improve correlations between them.

Several relational studies have been recently published on cheeses such as Italian cheeses [16], Brie [29], Emmental [12, 13, $35,36]$, Cheddar $[9,10,25]$ and Parmigiano Reggiano [31, 42]. Relational studies about texture in cheese came up against several difficulties. There was a lack of a standardised method for sensory texture as well as for rheological measurements. Moreover, the use of appropriate statistical methods including experimental design was limited. Jack et al. [25] used the partial least square regression to investigate relationships between instrumental and sensory data from different varieties of Cheddar cheese. However, in their study, the rheological method suffered criticisms [41] and the sensory analysis was based on a free profile. Suitable statistical methods have been recently reviewed [43].

The main purpose of the FLAIR European programme SENS (Food Linked Agro-Industrial Research, concerted action 0025 / COST 902) was to relate sensory and instrumental analysis of foods. Within this framework, much work was focused on cheese and especially 'Appellation d'Origine Protégée’ (A.O.P.) cheese varieties. Three groups of participants concentrated their evaluations and development work on sensory, rheological and biochemical methods, respectively. The sensory group developed a procedure for sensory analysis of texture [27]. The biochemical methods studied were initially focused on the determination of the extent and nature of proteolysis comprising $\mathrm{N}$ fractionation, electrophoresis, HPLC peptide mapping and determination of free amino acid composition $[5,6,7,14,15,33]$.

The main objective of this study was to evaluate relations between sensory textural and instrumental data measured on hard and semi-hard cheese. Two very different A.O.P. cheese varieties were used, i.e., Appenzeller, a semi-hard cheese made in Switzerland, and Parmigiano Reggiano, a hard Italian cheese. These cheese varieties were chosen 
to offer a great variability in the biochemical parameters related to texture. Pairwise relationships were explored between sensory texture and rheological measures on one side, and chemical and biochemical results on the other side. The very large difference between the two cheese varieties, however, does not allow any demonstration of causative relations, e.g., between biochemical and rheological parameters, for example. Indications of such relations should be further studied.

\section{MATERIALS AND METHODS}

\subsection{Cheese samples}

Two very different A.O.P. cheese varieties were studied, i.e., Appenzeller from Switzerland, a semi-hard cheese that melts slowly and regularly in the mouth revealing gradually its aroma, and Parmigiano Reggiano from Italy, that has a distinctive texture with a hard consistency and a granular structure [44]. The cheese samples were chosen to offer a great variability in the biochemical parameters related to texture. Ten samples per variety were selected to represent different ripening times and dairies, as required by statistical considerations. Age is commonly used as criteria for quality but it has been demonstrated that cheese samples of similar age could exhibit large differences in biochemical composition and sensory scores. Mature or old cheeses are sold at a minimum age of 4.5 months for Appenzeller and 18 months for Parmigiano Reggiano. Age of the samples selected for the study varied between 1.5 and 7.5 months for Appenzeller and between 6 and 28 months for Parmigiano Reggiano. Appenzeller samples are coded A 1 to A 10 and Parmigiano Reggiano samples P1 to P10 (see legend of figure 2).

Cheese samples were first gathered in the same place, then either sent to designated laboratories for sensory and rheological analysis which should be performed as soon as possible, or treated for biochemical analysis as described below.

Samples for sensory analysis were stored at $7{ }^{\circ} \mathrm{C}$, and placed at $16^{\circ} \mathrm{C}$ one or two hours before each sensory session. Samples for rheological analysis were stored at $7^{\circ} \mathrm{C}$ for no more than $5 \mathrm{~d}$. Before sample preparation and measurement, they were kept at the measuring tempera- ture $15 \pm 0.5^{\circ} \mathrm{C}$ for at least $12 \mathrm{~h}$ to allow thermal equilibration. The 20 cheese samples were collected and tested by sensory and rheological analysis over 2 weeks.

Several laboratories were involved in the biochemical analysis work and to ensure that subsamples were as similar as possible, the samples were grated, thoroughly mixed and placed into similar containers. They were packed under $\mathrm{CO}_{2}$ [17], stored at $-30^{\circ} \mathrm{C}$ for 4 weeks and finally sent under controlled mailing conditions to all participating laboratories. Samples were kept frozen until used, and before biochemical analysis they were put at $+5^{\circ} \mathrm{C}$ overnight and then one hour at $20-25^{\circ} \mathrm{C}$.

\subsection{Sensory analysis}

The sensory analysis method for the texture of hard and semi-hard cheese developed by Lavanchy et al. [27] was applied. It included the evaluation of mechanical, geometrical and surface properties. A possible homology between sensory and instrumental characteristics can be anticipated for the mechanical properties but not for the geometrical and surface textural ones. Thus only the mechanical properties, firmness, elasticity, deformability, friability and adhesivity were evaluated. All the cheeses were tested by 12 assessors at the Federal Dairy Research Institute, FAM (Liebefeld-Bern, Switzerland). Assessors were regularly trained and were familiar with sensory analysis of different cheeses. The cheeses were analysed as described below under the title 'design of sensory study' (statistical analysis). All the assessors received the reference products that are listed in the procedure [27]. Neutralising agents, black tea and water, were at the disposal of the panellists during each session.

\subsection{Rheological method}

Samples were analysed by uniaxial compression. Cylindrical samples ( $15 \mathrm{~mm}$ height, $12 \mathrm{~mm}$ diameter; height to diameter ratio $=1.25$ ) were prepared with a cork-borer and a parallel-wire device. The cylinders were wrapped in plastic film and left for about $1 \mathrm{~h}$ at the measuring temperature to allow relaxation. The compression test was performed by means of a universal testing machine (Zwick UPM 1435, DE) at a constant crosshead speed of $50 \mathrm{~mm} / \mathrm{min}$. No 
lubricant was used. Six replicates of each cheese sample were measured. Data acquisition was done using the original Zwick software (Druckvesuch an Schaumstoffen 5.1). Force (F) and height variation $(\Delta h)$ data were transferred as ASCII files to a spread sheet programme (Excel 4.0 , Microsoft) for the computation of stress at fracture (engineering stress $\sigma_{\mathrm{p}}$, unit: $\mathrm{kPa}$ ), strain at fracture (Cauchy strain $\varepsilon_{\mathrm{p}}$, no dimension), and work to fracture $\left(W_{f}\right.$, unit: $\left.\mathrm{kJ} / \mathrm{m}^{3}\right)$. Work to fracture, calculated as the area under the stress/strain curve, means the energy needed for the total deformation up to the apparent fracture point. The modulus of deformability $\mathrm{E}$ (unit: $\mathrm{kPa}$ ), which allows evaluation of the elastic properties, was approximated from the very first part of the smoothed first derivative of the stress/strain curve (Savitzky-Golay smoothing using TableCurve Windows 1.0, Jandel Scientific).

\subsection{Gross composition}

The gross composition was analysed using established methods, i.e., dry matter, DM [24], fat [22], ash [1], chloride [2], total calcium [32, adapted to the cheese by Jeunet (personal communication)], total N, TN [23]. The $\mathrm{pH}$ was determined, at ambient temperature, by using a penetrometric electrode (Mettler-Toledo, no. 104063123) on the cheese samples before sensory analysis. The parameters used in the multivariate and relational analyses were DM and Fat as $\mathrm{g} \cdot \mathrm{kg}^{-1}$ of cheese, and $\mathrm{TN}, \mathrm{NaCl}, \mathrm{Ca}$ and ash residue ([ash] $-[\mathrm{NaCl}]-[\mathrm{Ca}])$ as \% of DM, and $\mathrm{pH}$.

\subsection{Proteolysis}

$N$ fractionation: The $\mathrm{N}$ fractionation methods used were recently harmonised in an interlaboratory European FLAIR study [15]. The nitrogen fractions obtained were $\mathrm{pH} 4.4$ soluble $\mathrm{N}$ ( $\mathrm{pH} 4.4-\mathrm{SN}), 12 \%$ trichloroacetic acid soluble $\mathrm{N}$ (TCA-SN) and phosphotungstic acid soluble N (PTA-SN). Only minor modifications were made, i.e., the $\mathrm{pH} 4.4-\mathrm{SN}$ fraction was filtered at room temperature instead of at $30^{\circ} \mathrm{C}$ and the TCA$\mathrm{SN}$ fraction was kept over night at $5{ }^{\circ} \mathrm{C}$ instead of for $2 \mathrm{~h}$ at room temperature before filtration. All $\mathrm{N}$ fractions were determined twice. $\mathrm{N}$ content of each fraction was measured by the Kjeldahl method [23]. The $\mathrm{N}$ fractions, representing different sized $\mathrm{N}$ compounds, used for the multi- variate and relational analyses were the casein $\mathrm{N}(\mathrm{TN}-[\mathrm{pH} 4.4-\mathrm{SN}])$, the larger peptide $\mathrm{N}$ ([pH4.4-SN] - [TCA-SN]), the smaller peptide N ([TCA-SN] - [PTA-SN]) and the amino acid N ([PTA-SN]). These names were chosen to facilitate exposition with no ambition to exactly describe the content of each fraction. Peptides with different properties but the same size might be found in different fractions and the amino acid fraction contains not only amino acids but also very small peptides and minor $\mathrm{N}$ compounds. The $\mathrm{N}$ content of each fraction is expressed as $\%$ of TN.

Polyacrylamide gel electrophoresis (PAGE) of total cheese: Discontinuous PAGE was performed using the protocol of Andrews [4] and a vertical slab unit, $140 \times 160 \times 1.5 \mathrm{~mm}$ (LKB 2001, Bromma, Sweden), Tris- $\mathrm{HCl}$ pH 8.3 electrode buffer, constant current of $60 \mathrm{~mA}$, a voltage limited to $500 \mathrm{~V}$, power supply LKB 2197 with a stacking gel of $\mathrm{T}=5 \%, \mathrm{C}=4 \%$ with buffer Tris- $\mathrm{HCl}, \mathrm{pH} 7.6$ and a separation gel of $\mathrm{T}=9 \%, \mathrm{C}=5 \%$ with buffer Tris- $\mathrm{HCl}$, $\mathrm{pH} 8.9$, both containing $4.5 \mathrm{~mol} \cdot \mathrm{L}^{-1}$ urea. One gram of cheese was dispersed $\left(15 \mathrm{~min}, 40^{\circ} \mathrm{C}\right)$ in $40 \mathrm{~mL}$ stacking gel buffer containing $6 \mathrm{~mol} \cdot \mathrm{L}^{-1}$ urea and $0.1 \mathrm{~mol} \cdot \mathrm{L}^{-1} \beta$-mercaptoethanol. The slurry was then centrifuged $\left(3000 \mathrm{~g}, 4^{\circ} \mathrm{C}, 15 \mathrm{~min}\right)$ and $20 \mu \mathrm{L}$ bromophenol blue solution $(0.5 \% \mathrm{w} / \mathrm{v}$ in $50 \%$ ethanol) was added to $1 \mathrm{~mL}$ of supernatant as tracking dye. A volume of $5 \mu \mathrm{L}$ of this preparation was used as a sample. Gels were stained using a Coomassie brilliant blue G250 solution [11]. The absorbance of each band was measured at $590 \mathrm{~nm}$ (Transidyne General Co, Ann Arbor, MI, USA). Fractions were identified by reference to an isoelectric whole casein standard [4]. To estimate the casein composition, total area of the electrophoretogram as well as areas of the peaks corresponding to individual caseins $\left(\alpha_{\mathrm{S1}}-\mathrm{CN}\right.$, $\alpha_{\text {SI }}$ - I-CN, $\left.\beta-\mathrm{CN}, \beta-\mathrm{I}-\mathrm{CN}, \gamma-\mathrm{CN}\right)$ were measured. Proportion of individual caseins was expressed as a percent of the total area. The results for individual caseins could contain also unidentified breakdown products and may not strictly represent pure caseins.

Reverse-phase HPLC peptide mapping: The water soluble fraction was filtered $(0.45 \mu \mathrm{m}$, Millipore, Millex HV) and $50 \mu \mathrm{L}$ were injected onto a reverse phase (RP) column (Nucleosil, C18, $250 \mathrm{~mm} \times 4.6 \mathrm{~mm}$, size of particles: $5 \mu \mathrm{m}$, porosity: $300 \AA$, at $40^{\circ} \mathrm{C}$ ) and analysed with HPLC (625LC Waters, Milford, MA., USA). Absorption was recorded at $214 \mathrm{~nm}$ and data were collected on a PC based system (Maxima 820 , Waters, MA, USA). To reduce the number of 
variables to 16 , the areas of peaks (A-P) expressed as arbitrary units were pooled in the same manner for all the samples but in such a way that discriminating information was kept. Figure 1 gives the correspondence between peaks A-P and the retention time intervals on one example of chromatogram for each cheese variety.

Free Amino Acid composition: The composition of free amino acids was analysed with ionexchange chromatography [34]. A standard solution made by adding AABA, GABA, asp, glu and cit to a commercial amino acid standard (Pierce 20088) was used to establish the calibration curves. Data were collected on a PC equipped with Waters Baseline 810 software. The content of each amino acid was expressed as $\%$ of the total amounts of FAA (w/w).

\subsection{Statistical analysis}

Design of sensory study: In this study 12 assessors evaluated 20 samples in 5 sessions of 4 samples per session. The 10 samples of Appenzeller and 10 samples of Parmigiano Reggiano were randomly allocated to sessions ( 2 of each per session). In order to maximize the information on samples and to reduce variability and bias, the order of presentation of samples to each assessor was controlled by the experimental design [30]. The experimental design for each session was based on sets of three mutually orthogonal latin squares of size 4 . Each assessor was assigned to a row of one of the squares and order of presentation to the columns. This design ensured that each assessor tested each sample, each sample to be tested three times in each position and each sample followed every other sample.

Univariate analysis of sensory study: Each sensory variable was analysed in turn by analysis of variance. The block model allowed for assessor effects and session within assessor effects. The treatment model estimated means for each cheese, together with an average standard error of the difference between two means, and also order effects.

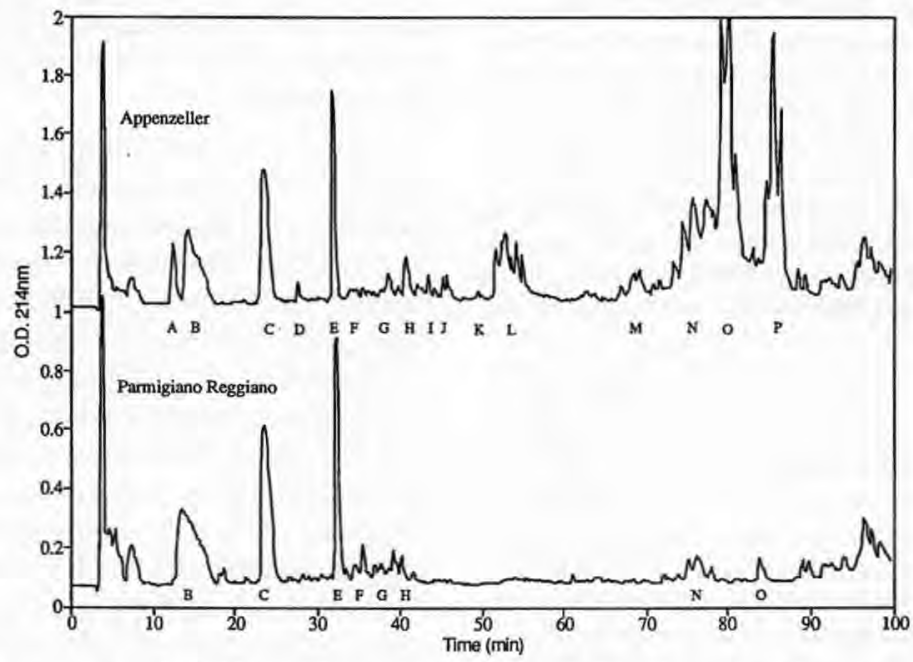

Figure 1. Reverse-phase HPLC peptide mapping represented by the optical density at $214 \mathrm{~nm}$ (OD) vs time, with the correspondance between $\mathrm{A}-\mathrm{P}$ peaks and the retention time intervals. Peptides were eluted at $1 \mathrm{~mL} \cdot \mathrm{min}^{-1}$ by a $10 \mathrm{~min}$ isocratic phase of solvent A (trifluoroacetic acid [TFA] $0.12 \%$ $(\mathrm{v} / \mathrm{v})$ in ultra high quality water) followed by a linear gradient of solvent B (TFA $0.10 \%$ (v/v) in acetonitrile $60 \%(\mathrm{v} / \mathrm{v}))$ increasing from 0 to $80 \%$ in $80 \mathrm{~min}$.

Figure 1. Cartographie peptidique HPLC en phase inverse représentant la densité optique à $214 \mathrm{~nm}$ (DO) en fonction du temps, avec la correspondance entre les pics A - P et les intervalles de temps de rétention. Les peptides sont élués à $1 \mathrm{~mL} \cdot \mathrm{min}^{-1}$ par une phase isocratique pendant $10 \mathrm{~min}$ du solvant A (acide trifluoroacétique [TFA] $0,12 \%(\mathrm{v} / \mathrm{v})$ dans de l'eau d'ultra-haute qualité) suivie par un gradient linéaire du solvant B (TFA 0,10\% (v/v) dans l'acétonitrile $60 \%(\mathrm{v} / \mathrm{v}))$ de 0 à $80 \%$ en $80 \mathrm{~min}$. 
Multivariate analysis of sensory and instrumental data: For all calculation variables were scaled to zero mean and unit variance. The tables of estimated cheese effects were summarised by principal component analysis (PCA). A 'scree' diagram of the eigen values was drawn and the number of components was determined empirically. Each group of results is presented in the form of a biplot [26] of the two first principal components (PC1 and PC2). This form of summary allows both the samples and the variables to be simultaneously presented on the same graphic. The original table of samples by variables can be approximated to by adding to the column (variable) mean the product of the distances of each sample and variable from the origin and the cosine of the angle between them. Consequently, samples and variables close to the centre have little variability whilst those far from the centre are very variable. If a sample and variable lie in the same direction and both are at a distance from the origin then this combination will have a high value whereas if they are in opposite directions the combination will have a low value. In order to further aid interpretation of the principal component scores, for each data set the scores have been correlated with the original variables.

Relational analysis: The simplest form of relational analysis is the correlation of one sensory variable with one instrumental variable. However, this allows only for simple linear relationships and several 'statistically significant' relationships may be identified simply because so many potential relationships have been tested. A more sophisticated method of relating data sets is by partial least squares regression (PLS) [28]. The particular form of the technique used in this study is PLS(1) in which one sensory variable is related to a set of instrumental variables. Based on their correlation with the sensory variable a different weight is attached to each instrumental variable of the set and so a linear combination of the instrumental variables is formed, known as a score by analogy with PCA. The calculations were done on the standardised measurements i.e., after transformation to give zero mean and unit variance. By operating on residuals the process is repeated a number of times. The number of scores justified is determined by cross-validation. The scores are then used to predict the sensory variable by fitting a regression to the sensory and score variables. The percentage variation accounted for by regression using three scores is given after calibration.

The statistical package used for analysis was GENSTAT 5.3.1 (Lawes Agricultural Trust 1993)

\section{RESULTS AND DISCUSSION}

\subsection{Multivariate analysis}

Sensory texture analysis: Sensory texture results are represented with a biplot diagram in figure 2. The two first principal components (PC1 and PC2) explained $94.3 \%$ of the total variability, with no significant contribution of the other principal components (table I). Elasticity, firmness, deformability and friability contributed at a high significant level $(P<.001)$ to $\mathrm{PC} 1$ (table I). PC2, with only one fifth of the total variability, was defined at a high significant level $(P<.001)$ by adhesivity. Elasticity and deformability were found quite close in figure 2; however, the experience clearly says that these two parameters are not directly correlated. Moreover there is no doubt that even trained assessors cannot evaluate deformability easily. Friability was associated with a high firmness, a low deformability and a-low elasticity, suggesting that friability could be considered as a secondary parameter.

Appenzeller and Parmigiano Reggiano samples were separated along PC1. Appenzeller samples were characterised by higher elasticity and deformability as well as lower friability and firmness than Parmigiano Reggiano. Moreover Appenzeller samples were distributed in a fan figure along PC2, following an increasing gradient of adhesivity with the age. Adhesivity was shown not to be a discriminating variable for Parmigiano Reggiano. The two youngest Parmigiano Reggiano samples P1 and P2 (both 6-months old) were discriminated along axis 1 (figure 2) with a higher elasticity and deformability, a lower friability and firmness for the sample P1 than for the sample P2. Cheese sample P4 (13-month old) had a central location on the biplot, indicating mean values for the different textural attributes.

Rheological analysis: The rheological results are represented with a biplot Diagram in figure 3. PC1 and PC2 explained $98.3 \%$ of the total variability, slightly higher 


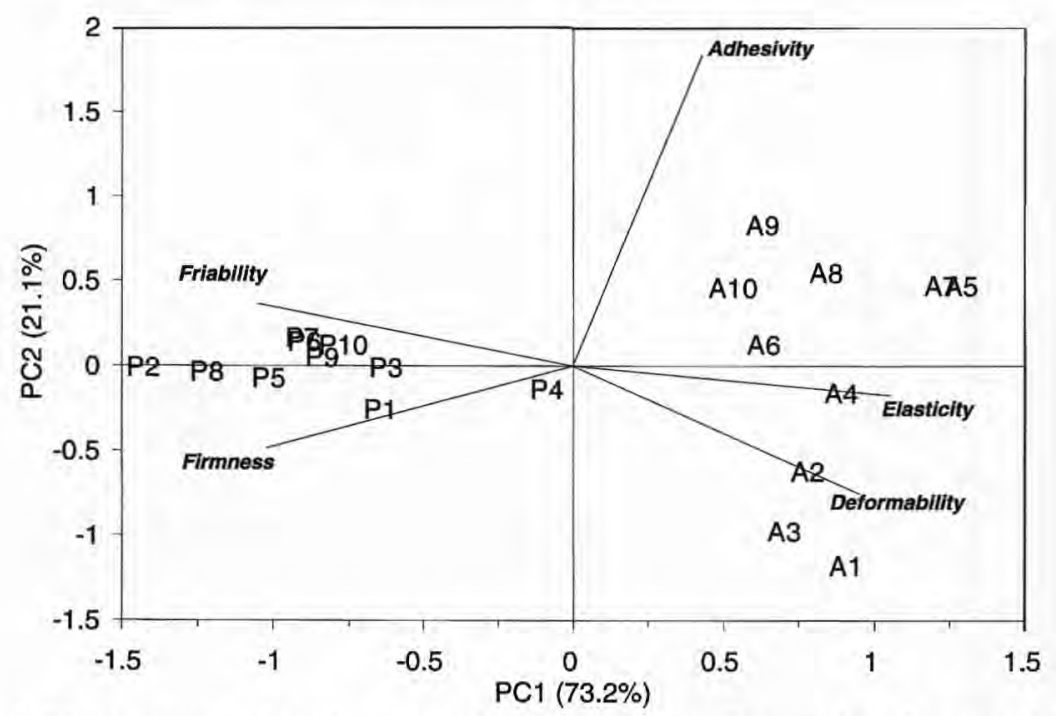

Figure 2. Biplot representation of sensory textural data. Appenzeller sample codes (age): A1 (53 d), A2 (68 d), A3 (75 d), A4 (114 d), A5 (131 d), A6 (170 d), A7 (192 d), A8 (216 d), A9 (218 d), A10 (223 d). Parmigiano Reggiano sample codes: P1 (180 d), P2 (180 d), P3 (360 d), P4 (390 d), P5 (480 d), P6 (510 d), P7 (510 d), P8 (660 d), P9 (750 d), P10 (840 d).

Figure 2. Représentation biplot des données sensorielles de texture. Codes des échantillons d'Appenzeller (âge) : A1 (53 jours), A2 ( 68 jours), A3 ( 75 jours), A4 (114 jours), A5 (131 jours), A6 (170 jours), A7 (192 jours), A8 (216 jours), A9 (218 jours), A10 (223 jours). Codes des échantillons de Parmigiano Reggiano : P1 (180 jours), P2 (180 jours), P3 (360 jours), P4 (390 jours), P5 (480 jours), P6 (510 jours), P7 (510 jours), P8 (660 jours), P9 (750 jours), P10 ( 840 jours).

than with the sensory textural data (table I). Stress and strain at fracture had the highest correlation with $\mathrm{PC} 1$ and $\mathrm{PC} 2$, respectively. Modulus of deformability and work to fracture variability were shared by $\mathrm{PC} 1$ and $\mathrm{PC} 2$, highly significantly to both.

The biplot (figure 3) gave evidence of three clusters. One cluster discriminated the three youngest Appenzeller cheeses (up to 2.5-months old) from the others by higher values of work to, strain and stress at fracture and low values of the modulus of deformability. The two youngest cheeses in the second cluster, A4 and A5, were directed towards the first cluster with the very youngest Appenzeller. The third cluster included medium-aged and old Parmigiano Reggiano, with the oldest ones (21-28 months) slightly away from the medium-aged ones.
This cluster was characterised by high values of modulus of deformability and low values of strain at fracture and work at fracture and also by medium values of stress at fracture. $\mathrm{PC} 1$ discriminated both the cheese varieties according to their ages, suggesting that age effect on these rheological parameters was quite simple and strong. The two cheese varieties were more discriminated along the axis represented by the vector of the modulus of deformability in the biplot.

The youngest cheeses (A1 to A3, P1 and $\mathrm{P} 2$ ) were associated to higher strain at fracture and work to fracture and the oldest to higher modulus of deformability. The youngest Parmigiano Reggiano P1 and P2 (6-month old) could appear as a distinct cluster as they were located in the same direction as the youngest Appenzeller. But they were in a 
Table I. Significant correlation between original sensory, rheological, chemical and biochemical parameters and principal components (18 degrees of freedom; $P<0.05$ : corr. $>0.444 ; P<0.01$ : corr. $>0.561 ; P<0.001$ : corr. $>0.679$ ).

Tableau I. Corrélations significatives entre les paramètres sensoriels, rhéologiques, chimiques et biochimiques et les composantes principales (18 ddL; $p<0,05$ : corr. $>0,444 ; p<0,01$ : corr. $>0,561 ; p<0,001$ : corr. $>0,679$ ).

\begin{tabular}{|c|c|c|c|c|c|c|c|c|c|c|}
\hline & & \multicolumn{4}{|c|}{ Principal components } & & \multicolumn{4}{|c|}{ Principal Components } \\
\hline & & 1 & 2 & 3 & 4 & & 1 & 2 & 3 & 4 \\
\hline \multirow{2}{*}{\multicolumn{2}{|c|}{$\begin{array}{l}\text { SENSORY TEXTURE } \\
\text { Variability explained (\%) }\end{array}$}} & & & & & \multicolumn{5}{|l|}{ PEPTIDE-HPLC } \\
\hline & & 73.2 & 21.1 & - & - & Variability explained (\%) & 56.4 & 18.5 & 9.6 & 4.9 \\
\hline & & & & & & \multicolumn{5}{|l|}{ Retention Interval } \\
\hline & Elasticity & 0.969 & - & - & - & A & 0.486 & 0.686 & - & - \\
\hline & Firmness & -0.936 & - & - & - & B & -0.922 & - & - & - \\
\hline & Deformability & 0.874 & - & - & - & $\mathrm{C}$ & -0.834 & - & - & - \\
\hline & Friability & -0.962 & - & - & - & $\mathrm{D}$ & - & 0.833 & - & - \\
\hline \multirow{2}{*}{\multicolumn{2}{|c|}{ Adhesivity }} & - & 0.906 & - & - & $\mathrm{E}$ & -0.810 & - & - & - \\
\hline & & & & & & $\mathrm{F}$ & -0.702 & - & - & 0.524 \\
\hline & RHEOLOGY & & & & & G & - & 0.635 & - & -0.486 \\
\hline & Variability explained (\%) & 60.5 & 37.8 & - & - & $\mathrm{H}$ & 0.816 & - & - & - \\
\hline & & & & & & I & 0.686 & 0.490 & - & - \\
\hline E & modulus of deformability & -0.804 & 0.583 & - & - & $\mathbf{J}$ & 0.844 & - & - & - \\
\hline$\sigma_{\mathrm{f}}$ & fracture stress & - & 0.946 & - & - & $\mathrm{K}$ & 0.768 & -0.608 & - & - \\
\hline & fracture strain & 0.951 & - & - & - & $\mathrm{L}$ & 0.793 & 0.535 & - & - \\
\hline \multirow{4}{*}{\multicolumn{2}{|c|}{$\mathrm{W}_{\mathrm{f}}$ work to fracture }} & 0.877 & 0.463 & - & - & M & 0.907 & - & - & - \\
\hline & & & & & & $\mathrm{N}$ & 0.889 & - & - & - \\
\hline & & & & & & $\mathrm{O}$ & 0.785 & - & 0.579 & - \\
\hline & & & & & & $\mathrm{P}$ & 0.761 & - & 0.630 & - \\
\hline
\end{tabular}


Table I. (continued) / Tableau I (suite).

\begin{tabular}{|c|c|c|c|c|c|c|c|c|c|}
\hline \multicolumn{5}{|l|}{ GROSS COMPOSITION } & \multicolumn{5}{|l|}{ AMINO ACIDS } \\
\hline Variability explained (\%) & 72.7 & 11.1 & 6.0 & - & Variability explained $(\%$ & 61.2 & 18.5 & 10.9 & 3.5 \\
\hline $\mathrm{pH}$ & -0.782 & - & - & - & Asp & 0.772 & 0.468 & - & - \\
\hline $\mathrm{DM}$ & 0.747 & - & 0.527 & - & Thr & 0.909 & - & - & - \\
\hline $\mathrm{NaCl}(\% \mathrm{DM})$ & -0.726 & 0.482 & - & - & Ser & 0.933 & - & - & - \\
\hline Calcium (\% DM) & 0.917 & - & - & - & Asn & - & -0.826 & - & - \\
\hline$a \operatorname{ash}-(\mathrm{Ca}+\mathrm{NaCl})$ & 0.889 & - & - & - & Glu & - & 0.964 & - & - \\
\hline fat & -0.944 & - & - & - & Gln & - & -0.638 & - & - \\
\hline \multirow[t]{2}{*}{$\mathrm{TN}$} & 0.931 & - & - & - & Gly & 0.765 & 0.583 & - & - \\
\hline & & & & & Ala & 0.924 & - & - & - \\
\hline \multicolumn{2}{|l|}{ N FRACTIONS } & & & & Cit & 0.764 & - & - & 0.547 \\
\hline \multirow[t]{2}{*}{ Variability explained (\%) } & 59.2 & 37.9 & - & - & $\mathrm{AABA}$ & -0.551 & 0.559 & - & - \\
\hline & & & & & Val & -0.480 & 0.778 & - & - \\
\hline \multirow{5}{*}{$\begin{array}{l}\text { Casein } \mathrm{N}^{1} \\
\text { Larger peptide } \mathrm{N}^{1} \\
\text { Smaller peptide } \mathrm{N}^{1} \\
\text { Amino acid } \mathrm{N}^{1}\end{array}$} & -0.949 & - & - & - & Cys & -0.722 & - & - & - \\
\hline & - & 0.943 & - & - & Leu & -0.951 & - & - & - \\
\hline & 0.825 & 0.519 & - & - & Tyr & 0.801 & - & - & - \\
\hline & 0.838 & -0.523 & - & - & Phe & -0.950 & - & - & - \\
\hline & & & & & Met & 0.616 & 0.631 & - & - \\
\hline \multicolumn{5}{|c|}{ ELECTROPHORESIS PARAMETERS } & Ile & 0.914 & - & - & - \\
\hline \multirow[t]{2}{*}{ Variability explained (\%) } & 61.9 & 21.9 & 10.8 & - & GABA & - & -0.715 & - & - \\
\hline & & & & & $\operatorname{Trp}$ & 0.818 & - & - & - \\
\hline$\beta-\mathrm{CN}$ & 0.959 & - & - & - & Orn & -0.902 & - & - & - \\
\hline$\alpha_{s 1}-\mathrm{CN}$ & 0.733 & - & -0.588 & - & Lys & -0.872 & - & - & - \\
\hline$\alpha_{s 1}-\mathrm{I}-\mathrm{CN}$ & 0.889 & - & - & - & His & 0.486 & -0.755 & - & - \\
\hline$\gamma-\mathrm{CN}$ & -0.917 & - & - & - & Arg & 0.604 & - & - & -0.694 \\
\hline$\beta-\mathrm{I}-\mathrm{CN}$ & - & 0.962 & - & - & Pro & -0.786 & - & -0.612 & - \\
\hline
\end{tabular}

${ }^{1}$ Casein $\mathrm{N}=\mathrm{TN}-[\mathrm{pH} 4.4-\mathrm{SN}]$; Larger peptide $\mathrm{N}=[\mathrm{pH} 4.4-\mathrm{SN}] ;-[\mathrm{TCA}-\mathrm{SN}$.

Smaller peptide $\mathrm{N}=[\mathrm{TCA}-\mathrm{SN}]-[\mathrm{PTA}-\mathrm{SN}]$; Amino acid N = [PTA-SN]; see Materials and Methods for details. 


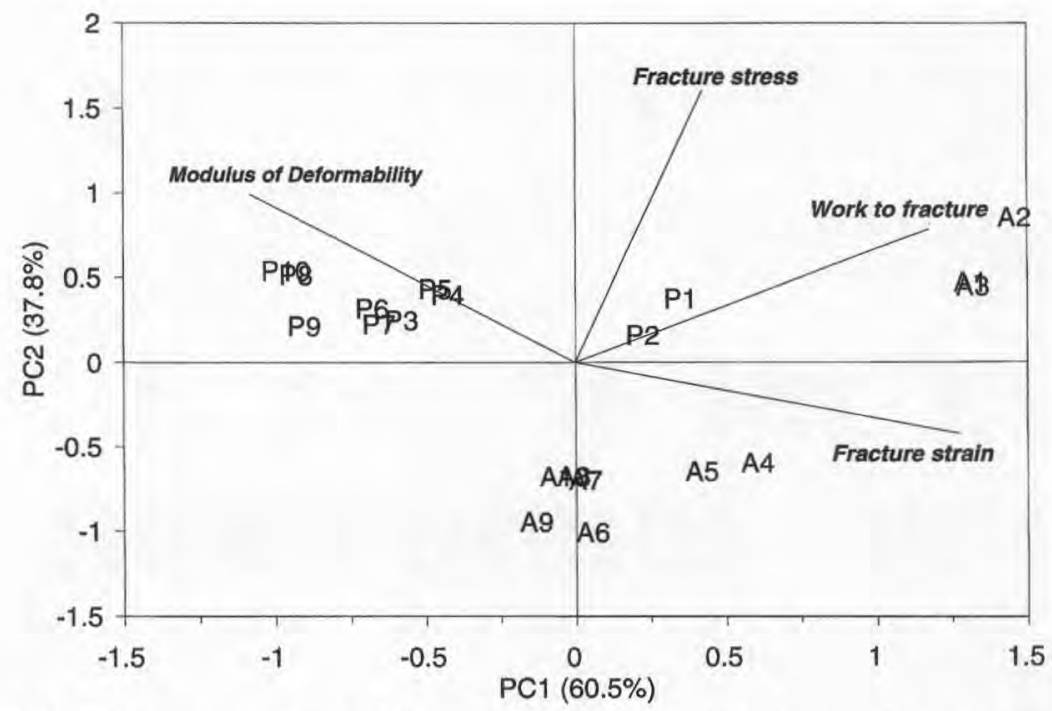

Figure 3. Biplot representation of rheological data. A1 to A10: Appenzeller samples; P1 to P10: Parmigiano Reggiano samples (see legend in figure 2).

Figure 3. Représentation biplot des données rhéologiques. A1 à A10 : échantillons d'Appenzeller ; P1 à P10 : échantillons de Parmigiano Reggiano (voir légende de la figure 2).

more central location due to the lower values of strain at and work to fracture and medium value of stress at fracture.

Gross composition: Gross composition results are represented on a biplot Diagram in figure 4 . The main part of the variability $(72.7 \%)$ was described by PC1, which also discriminated the 2 cheese varieties. All the parameters contributed to $\mathrm{PC} 1$ at a high significant level $(P<.001$, table $I)$. TN and Ca were at the very same place on the biplot, indicating a close relationship.

PC2 described $11.1 \%$ of the variability, which appeared to be mainly due to differences in $\mathrm{NaCl}$ contents $(P<.05)$. DM content contributed significantly to $\mathrm{PC} 3$ $(P<.05)$ which described $6 \%$ of the variability (table I).

Proteolysis by $N$ fractionation: The two first principal components represent $97 \%$ of the total variability of the nitrogen fractionation data (figure 5). $\mathrm{PC} 1$ is described at a high significant level $(P<.001)$ by the casein $\mathrm{N}([\mathrm{TN}]$ - [pH4.4-SN]) in one direction and both smaller peptide N ([TCA$\mathrm{SN}]$ - [PTA-SN]) and amino acid $\mathrm{N}$ ([PTA-SN]) in the other (table I). The youngest cheese samples of both varieties were associated with the largest values of casein $\mathrm{N}$ and the oldest ones by larger values for the smaller peptide $\mathrm{N}$ and amino acid $\mathrm{N}$ as could be expected. PC2 discriminated Appenzeller from Parmigiano Reggiano cheeses mainly because of the occurrence of peptide $\mathrm{N}$ compounds, which were poorly represented in Parmigiano Reggiano.

As on the sensory texture biplot the two youngest Parmigiano Reggiano samples P1 and $\mathrm{P} 2$ were discriminated on the $\mathrm{N}$ fractionation biplot (figure 5). However sample $\mathrm{P} 2$ could not be considered as more mature than sample $\mathrm{P} 1$, as was suggested by the sensory texture biplot, but rather having a different proteolysis pattern. Sample P2 was related more strongly to large amount of casein $\mathrm{N}$ than sample P1. 


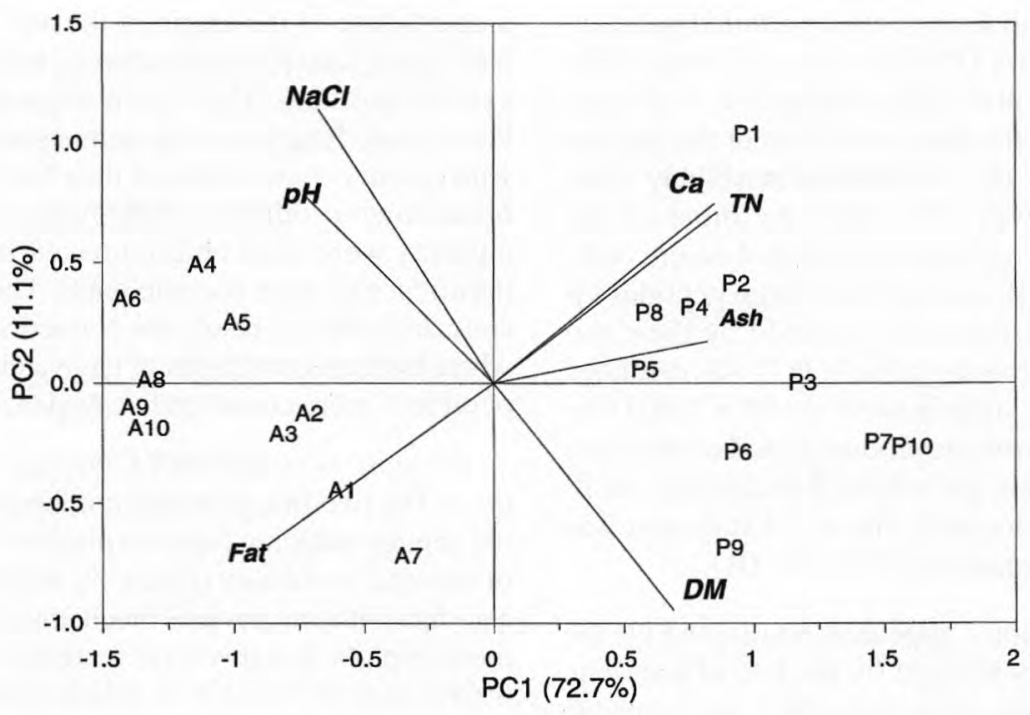

Figure 4. Biplot representation of gross composition data (DM, dry matter - TN, total nitrogen). A1 to A10: Appenzeller samples; P1 to P10: Parmigiano Reggiano samples (see legend figure 2).

Figure 4. Représentation biplot des données de composition chimique (DM, extrait sec-TN, azote total). A1 à A10 : échantillons d'Appenzeller ; P1 à P10 : échantillons de Parmigiano Reggiano (voir légende figure 2).

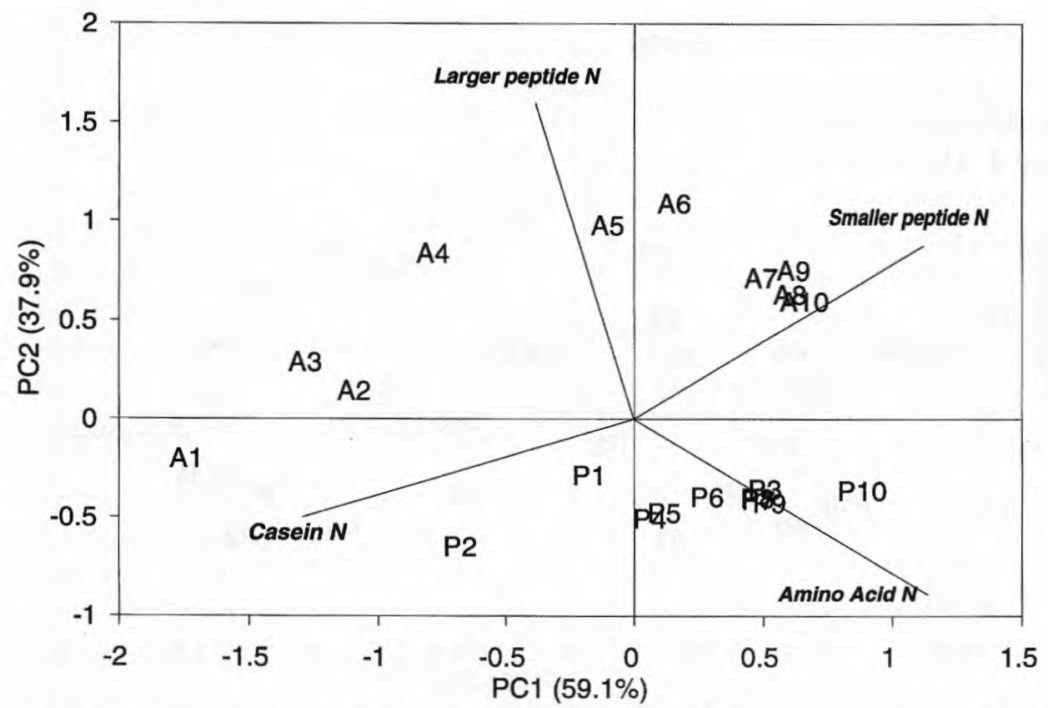

Figure 5. Biplot representation of $\mathrm{N}$ fractionation data. A1 to A10: Appenzeller samples; P1 to P10: Parmigiano Reggiano samples (see legend figure 2).

Figure 5. Représentation biplot des fractions azotées. A1 à A10 : échantillons d'Appenzeller ; P1 à P10 : échantillons de Parmigiano Reggiano (voir légende figure 2). 
Proteolysis by polyacrylamide gel electrophoresis (PAGE) of total cheese: The two first principal components explained $83.8 \%$ of the total variability of the data set (figure 6). $\mathrm{PC1}$ was defined at a highly significant level $(P<.001)$ by most of the variables representing original casein components $\left(\beta\right.$, and $\left.\alpha_{s 1}\right)$ and large peptides $(\gamma-$ and $\alpha_{\mathrm{s} 1}$-I-caseins) produced by their primary hydrolysis (table I). PC2 was described at a high significant level $(P<0.001)$ by other hydrolysis product found on the electrophoresis gel where $\beta$-I casein from $\beta$ casein is located. The $\alpha_{\mathrm{s1}}-\mathrm{I}$ fragment was also associated to PC3 $(P<.01)$.

The biplot appeared dominated by the variability brought by the fate of $\beta$-casein. This pattern suggests that $\mathrm{PC} 1$ was related to plasmin type of activity and PC2 to rennet type of activity on $\beta$-casein. Sample distribution in the plot failed to show neither a clear separation of cheese varieties nor a layout according to age. However, there was a tendency of Appenzeller samples to be located close to the origin of the axis whereas Parmigiano Reggiano cheeses had more extreme positions. This layout suggests that Parmigiano Reggiano was more associated with casein components and their first large breakdown products, while Appenzeller cheeses were also characterised by the occurrence of other $\mathrm{N}$ compounds. This was consistent with the results for $\mathrm{N}$ fractionation where high concentrations of large and small peptide $\mathrm{N}$ were connected to Appenzeller.

Proteolysis by RP-HPLC peptide mapping: The two first principal components in the peptide mapping biplot explained $74.9 \%$ of the total variability (figure 7), which was less than with the previous biochemical parameter biplots. But this level increased up to $89.4 \%$ with PC3 and PC4, which contributed significantly to the variability.

PC1 was determined at a high significant level $(P<.001)$ by most peak intervals except $\mathrm{D}$ and $\mathrm{G}$ and with a lesser significance by $\mathrm{A}(P<.05)$ (table $I)$. It completely separated Parmigiano Reggiano from

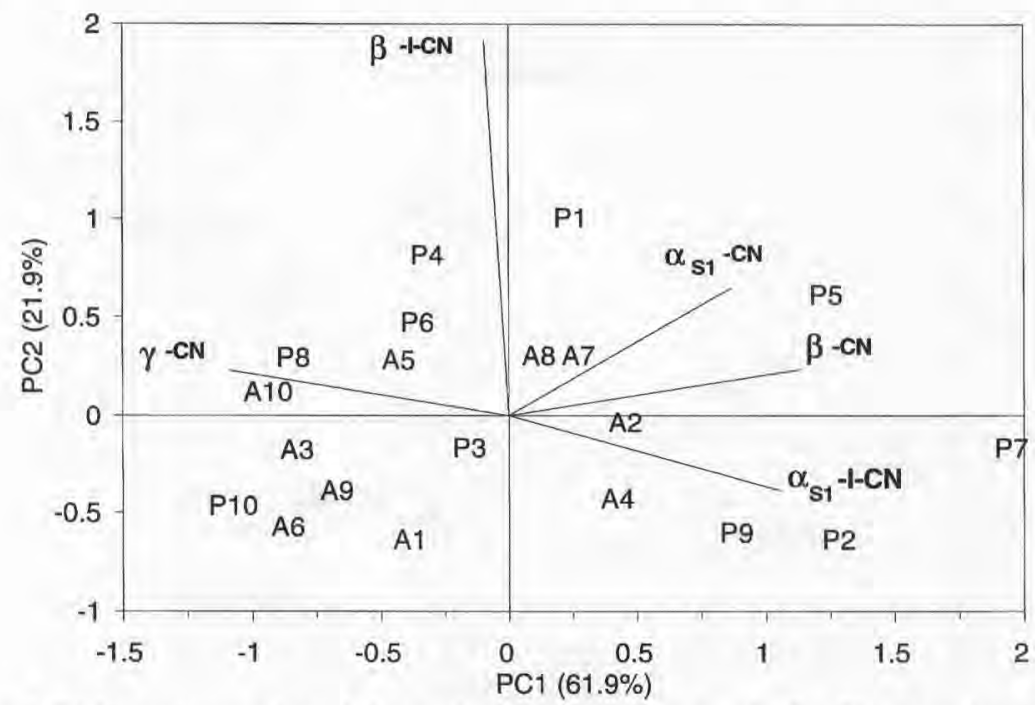

Figure 6. Biplot representation of electrophoresis data $\left(\alpha_{\mathrm{S1}}, \alpha_{\mathrm{S1}}-\mathrm{I}-, \beta-, \beta \mathrm{I}-, \gamma\right.$-casein $)$. A1 to A10: Appenzeller samples; P1 to P10: Parmigiano Reggiano samples (see legend figure 2).

Figure 6. Représentation biplot des données d'électrophorèse (caséines $\alpha_{\mathrm{SI}}, \alpha_{\mathrm{S} 1}-\mathrm{I}, \beta, \beta \mathrm{I}, \gamma$ ). A1 à A10 : échantillons d'Appenzeller; P1 à P10 : échantillons de Parmigiano Reggiano (voir légende figure 2). 


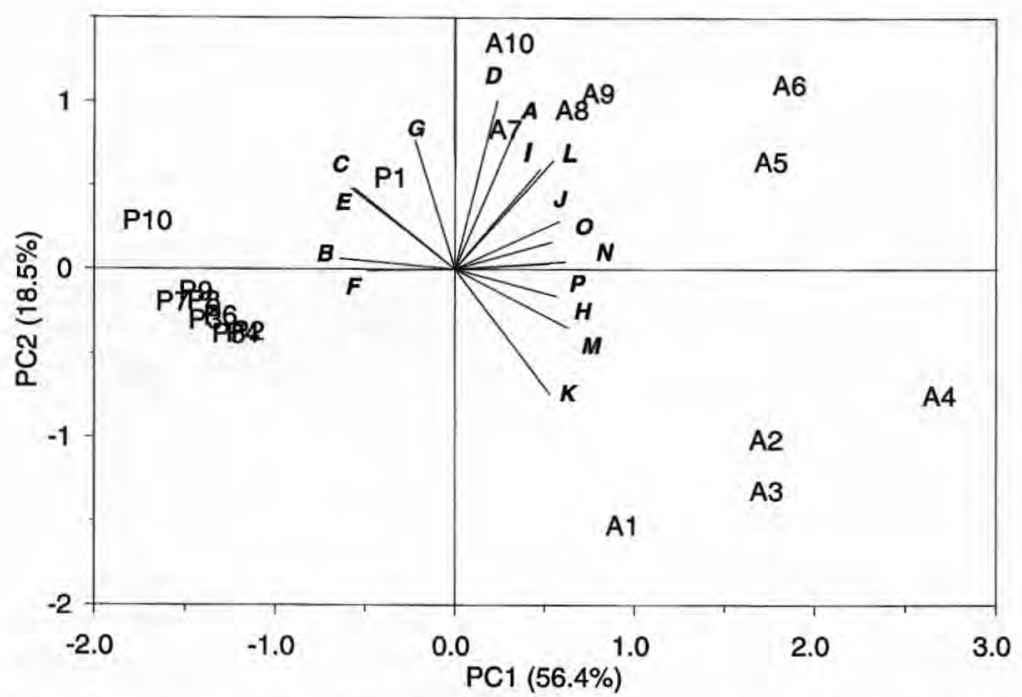

Figure 7. Biplot representation of reverse-phase HPLC peptides mapping data (peaks A to P, see figure 1). A1 to A10: Appenzeller samples; P1 to P10: Parmigiano Reggiano samples (see legend figure 2).

Figure 7. Représentation biplot des données de cartographie peptidique par HPLC en phase inverse (pics $\mathrm{A}$ à $\mathrm{P}$, voir figure 1). A1 à $\mathrm{A} 10$ : échantillons d'Appenzeller; $\mathrm{P} 1$ à $\mathrm{P} 10$ : échantillons de Parmigiano Reggiano (voir légende figure 2).

Appenzeller cheeses. The most hydrophobic peptides which eluted late (intervals $\mathrm{H}-\mathrm{P}$ ) all contributed strongly to PC1. Also contributing to $\mathrm{PCl}$ but in the opposite direction were the earlier eluted components in intervals B, C, E, and F (table I). Interval A contributed to a smaller extent $(P<.05)$ in the same direction as H-P. Peak intervals $\mathrm{B}, \mathrm{C}$ and $\mathrm{E}$ had retention times similar to the hydrophobic amino acids tyrosine, phenylalanine and tryptophan, respectively. Thus it was not surprising that Parmigiano Reggiano cheeses known for their high concentrations of amino acids were found in a cluster close to the large concentrations of these three peaks. As seen before, sample P1 behaved somewhat differently to the other Parmigiano Reggiano. The Appenzeller samples were connected to $\mathrm{PC} 1$ due to the presence of larger amounts of material in peak intervals H - P than Parmigiano Reggiano cheeses. The mature Appenzeller were close to Parmigiano Reggiano cheeses according to PC1 than the younger ones.
Furthermore $\mathrm{PC} 2$, which were highly defined by intervals $\mathrm{A}$ and $\mathrm{D}(P<.001)$, and to some extent also by $\mathrm{G}, \mathrm{K}$ and $\mathrm{L}(P<.01)$ (table $I$ ) was directed by parameters that changed according to the age of Appenzeller. The youngest Appenzeller cheeses were associated to large contents of compounds eluted in peak interval $\mathrm{K}$.

Proteolysis by free amino acids analyses: The two first PC:s explained $79.7 \%$ of the total variability (figure 8). PC3 also explained significantly further $10.9 \%$. Except asn, glu, gln, val, GABA, his, all the amino acids contributed significantly to PC1 (table I) which discriminated the two cheese varieties. The Parmigiano Reggiano samples were found connected to larger amounts of asp, thr, ser, gly, ala, cit, met, ile, tyr, trp, his and arg while the Appenzeller samples were distinguished by higher amounts of AABA, val, cys, leu, phe, orn, lys, and pro.

PC2 was described by 10 amino acids, i.e., at one side by mainly glu and val 


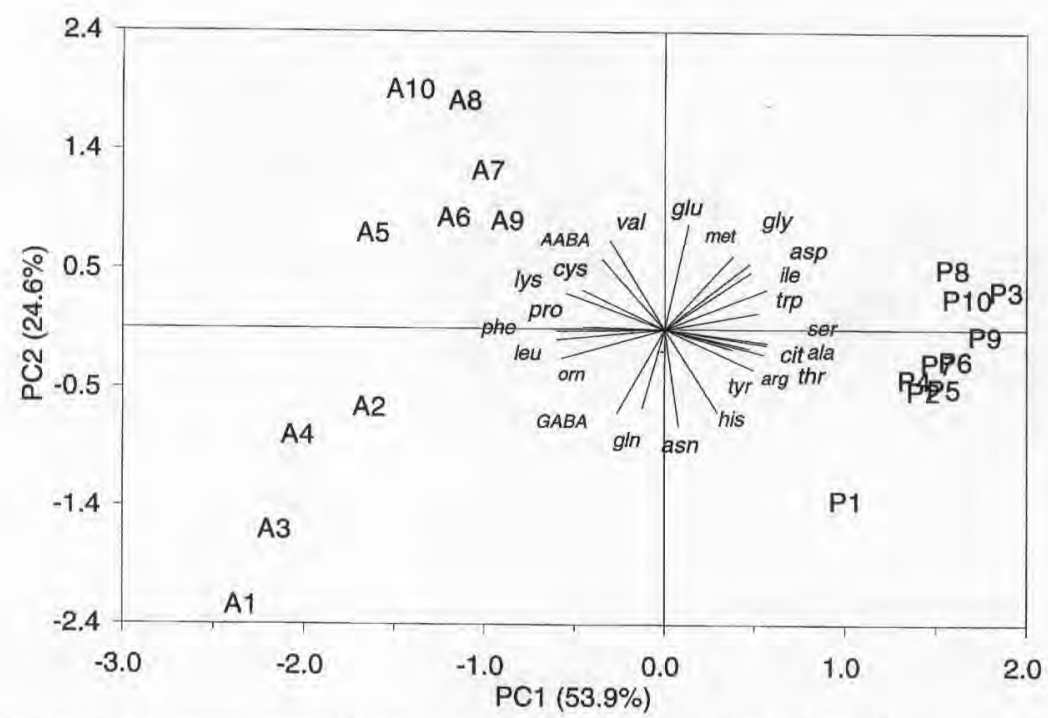

Figure 8. Biplot representation of amino acid composition data. A1 to A10: Appenzeller samples; P1 to P10: Parmigiano Reggiano samples (see legend figure 2).

Figure 8. Représentation biplot des données de composition en acides aminés. A1 à A10 : échantillons d'Appenzeller; P1 à P10 : échantillons de Parmigiano Reggiano (voir légende figure 2).

$(P<0.001)$ and to a lesser extent by met, gly, AABA $(P<0.01)$, asp $(P<0.05)$ and at the opposite side by asn, GABA, his $(P<0.001)$ and $\operatorname{gln}(P<0.01)$. PC2 separated the cheeses mainly from their ages and was more effective for Appenzeller than for Parmigiano Reggiano samples. The youngest cheeses of both varieties, however, were clearly distinguished from the other cheeses by their relatively higher amounts of asn, gln, GABA and his, and the oldest one by higher amounts of glu and asp. This is in accordance with transformation of gln and asn to glu and asp, respectively, while cheese matures.

Arg and its breakdown product orn contributed significantly to $\mathrm{PC} 1$ in opposite directions as arg and its breakdown product cit did to PC4, indicating different sources for the two activities. Pro contributed significantly not only to PC1 but also as the only amino acid to PC3 (table I).

\subsection{Characteristic parameters for the two cheese varieties}

When a highly significant correlation is found between two data sets of this study it might not always be a result of a direct relation between the parameters. Another explanation could be that each of the two data sets very well characterises the cheeses and the high correlation is due to the main differences between the two cheese varieties. A major difference came from the age of the samples, with Parmigiano Reggiano samples mostly older than Appenzeller ones due to the range of normal consumption time. Consequently, age affected differently the textural properties of the two cheese varieties, which was evident drawing the parameters versus age (results not shown).

From the purpose of preventing incorrect conclusions being drawn from the results of this study, all parameters found to be larger at high significant level $(P<.001)$ in this study for Parmigiano Reg- 
giano and Appenzeller cheeses, respectively, are listed in (table II).

\subsection{Relational analysis and prediction of sensory}

Sensory texture versus rheology: The two first principal components from the rheological data set were correlated significantly with the two first principal components of the sensory data set (table III). This means that there were significant correlations (table I) between the four variables of the sensory PC1 (elasticity, friability, firmness and deformability), and the three variables of the rheological PC1 (strain at fracture, work to fracture and modulus of deformability). The statistical relationship between the sensory and rheological PC2 expressed a reverse relationship between adhesivity and stress at fracture (table I).

Rheological parameters could be useful for predicting sensory firmness, elasticity and friability results, and to a lesser extent adhesivity and deformability (table IV). The variation accounting for each sensory variable by the rheological parameters was always higher than $70 \%$, but less than for the peptide HPLC and amino acid compo- sition variables. The rheological analysis characterises the mechanical properties of the cheese structure, similar to the sensory analysis, while the chemical and biochemical analysis give more information about the components of the structure. Thus the fact that the prediction from rheology was not the best one, pointed out that sensory and rheological analysis do not evaluate exactly the same things. For example, Parmigiano Reggiano samples $\mathrm{P} 1$ and $\mathrm{P} 2$, which had the same age, appeared different from sensory, gross composition, $\mathrm{N}$ fractionation, HPLC and amino acids analysis, but seemed close together from rheology.

Sensory texture versus gross composition: Gross composition $\mathrm{PC} 1$ and $\mathrm{PC} 3$ were correlated to sensory PC1 and PC2 (table III). All the gross composition variables, which described PC1 (table I), were correlated to the four variables of the sensory PC1. Both PC1 explained more than $70 \%$ of the variability. It was interesting to notice that only the DM variable associated with the gross composition PC3 (6\% of the variability) was correlated with adhesivity representing mainly the sensory $\mathrm{PC} 2$, in a way which indicated a straight forward relation.

Appenzeller samples were characterised by high sensory elasticity and deformabi-

Table II. Characteristic parameters for the two cheese varieties from the results of the multivariate analysis, which were also found to be significantly different at a high level $(P<0.001)$.

Tableau II. Paramètres caractéristiques associés à chacune des deux variétés de fromages à partir de l'analyse multivariée, paramètres différents à un niveau hautement significatif $(p<0,001)$.

\begin{tabular}{ll}
\hline $\begin{array}{l}\text { Higher values characteristic to } \\
\text { Parmigiano-Reggiano }\end{array}$ & $\begin{array}{l}\text { Higher values characteristic to } \\
\text { Appenzeller }\end{array}$ \\
\hline $\begin{array}{l}\text { Firmness, friability } \\
\text { Acidity } \\
\text { Modulus of deformability } \\
\text { Ca, TN, DM, Ash-residue }\end{array}$ & Elasticity, deformability \\
Amino acid N ([PTA-SN]) & $\mathrm{pH}$, fat \\
$\begin{array}{l}\text { HPLC-peptide intervals: B, C, E } \\
\text { asp, thr, ser, ala, cit, ile, tyr, trp, his, arg } \\
\text { (\% total aa) }\end{array}$ & $\begin{array}{l}\text { Larger peptide N ([pH4.4-SN]-[TCA-SN]) } \\
\text { HPLC-peptide intervals: A, H, J - P } \\
\text { AABA, val, cys, leu, phe, orn, lys, pro } \\
\text { (\% total aa) }\end{array}$ \\
\hline
\end{tabular}

aa: amino acids. 
lity as well as low DM, high fat and $\mathrm{NaCl}$ content and $\mathrm{pH}$. Firmness and friability on the other hand were found related to Parmigiano Reggiano as well as higher value for DM, TN, Ca and ash residue. Similar results on relationships between water content and textural properties have been already mentioned $[13,20,38]$.

Sensory elasticity and firmness and at a lesser extent deformability and friability of the cheese samples could be predicted quite well from their gross composition (table IV). However gross composition did not appear useful to predict adhesivity.

The relationships between sensory texture attributes and proteolysis were explored here independently for each type of technique used to determine proteolysis. Combination of proteolytic measurements should be another step for further studies. Not many laboratories will have resources to perform all the analytical methods used in this study to characterise proteolysis in traditional cheeses. Only few people are initiated in all these methods. Furthermore, proteolysis is complicated and includes activities from different sources. Not very much is known about the influence on cheese texture from the different proteolytic activities. In order to estimate relations between the different proteolysis results, a matrix of dis-similarities (result not shown) was formed by pairwise general procrustes analysis [8] of the measures of protein breakdown. Electrophoresis and nitrogen fractions appeared to be close together, also HPLC peptides and amino acids.

Sensory texture versus $N$ fractionation: It was the $\mathrm{N}$ fractionation $\mathrm{PC} 2$ which was found correlated to sensory PC1 (table III) while the $\mathrm{N}$ fractionation $\mathrm{PC} 1$ was correlated to sensory PC2. Larger peptide $\mathrm{N}$ and at a lesser extent smaller peptide $\mathrm{N}$ and amino acid $\mathrm{N}$ appeared correlated to elasticity, firmness, deformability and friability (table I). Smaller peptide $\mathrm{N}$ and amino acid $\mathrm{N}$, but also casein $\mathrm{N}$ in the opposite direction were related to adhesivity which represented the sensory PC2.

It seemed that the cheese samples which had the highest contents of casein $\mathrm{N}$ and larger peptide $\mathrm{N}$ (figure 5) were also those which were the most elastic and deformable (figure 2), namely young Appenzeller. Samples with high amino acid $\mathrm{N}$ content were those that were found most firm and friable (Parmigiano Reggiano). Peptides from the fraction of smaller peptide $\mathrm{N}$ have

Table III. Significant correlation coefficients (ignoring sign) between the principal components of sensory and instrumental data sets (PC numbers are within brackets); 18 degrees of freedom; $P<0.05$ : corr. $>0.444 ; P<0.01$ : corr. $>0.561 ; P<0.001$ : corr. $>0.679$.

Tableau III. Coefficients de corrélation significativement différents entre les composantes principales des tableaux de données sensorielles et instrumentales (numéro de la composante principale entre parenthèses); 18 ddl ; $p<0,05$ : corr. $>0,444 ; p<0,01$ : corr. $>0,561 ; p<0,001$ : corr. $>0,679$.

\begin{tabular}{lcc}
\hline & \multicolumn{2}{c}{ Sensory Texture } \\
\cline { 2 - 3 } & PC1 & PC2 \\
\hline Rheology & $0.651(1)$ & $0.676(2)$ \\
Gross Composition & $0.859(1)$ & $0.606(3)$ \\
N Fractionation & $0.851(2)$ & $0.835(1)$ \\
Electrophoresis & - & - \\
Peptide-HPLC & $0.868(1)$ & $0.861(2)$ \\
Amino acid composition & $0.909(1)$ & $0.873(2)$ \\
\hline
\end{tabular}


Table IV. Variation of sensory texture attributes explained by instrumental data estimated by using PLS (1) method (see text for details).

Tableau IV. Variance des descripteurs de texture expliquée par les données instrumentales, estimée par la méthode PLS (1) (voir les détails dans le texte).

\begin{tabular}{lcccccc}
\hline & \multicolumn{5}{c}{ Variation explained by partial least square regression } \\
\cline { 2 - 6 } & Rheology & $\begin{array}{c}\text { Gross } \\
\text { composition }\end{array}$ & $\begin{array}{c}\text { N } \\
\text { fractionation }\end{array}$ & Electrophoresis & HPLC & Amino acids \\
\hline Elasticity & 83.1 & 85.7 & 80.2 & 38.3 & 92.5 & 97.1 \\
Firmness & 85.7 & 78.9 & 89.6 & 51.7 & 88.3 & 94.7 \\
Deformability & 71.0 & 74.0 & 61.9 & 30.1 & 76.2 & 86.9 \\
Friability & 78.9 & 73.8 & 79.3 & 46.8 & 84.3 & 90.9 \\
Adhesivity & 72.5 & 65.1 & 82.0 & 71.2 & 88.4 & 86.0 \\
\hline
\end{tabular}

been identified for Parmigiano Reggiano [3]. Most of the peptides identified were found to be phosphopeptides consisting about 5-20 amino acids and they could have been produced by peptidolytic activity on larger peptides originated from the plasmin activity on the casein components (mainly $\beta$-casein). Similar results were observed on another cheese variety, i.e., Comté [37]. It indicates relationships between adhesivity and hydrophilic peptides as well as content of available water as indicated above from the relation between adhesivity and DM.

$\mathrm{N}$ fractionation was found to be useful in predicting firmness, adhesivity, elasticity and friability as listed in table $I V$ with more than $79 \%$ of the variability explained. Surprisingly, deformability was not so well predicted by $\mathrm{N}$ fractionation $(61.9 \%)$.

Sensory texture versus electrophoresis: Although correlation between textural parameters of cheese and extent of casein components (especially $\alpha_{\mathrm{s} 1}$-casein) breakdown is referred to in the literature $[18,19,21]$, electrophoresis was found to be a poor method for the prediction of sensory texture in this study. No significant correlation between sensory texture and electrophoresis principal components was found (table III). Predictions using the PLS method were poor (table IV) for all texture parameters except adhesivity (71.2\%).
Sensory texture versus RP-HPLC peptide mapping: The first and the second principal components of sensory texture and HPLC peptide mapping were highly correlated to each other (table III). This indicated correlations between elasticity, firmness, deformability and friability, which contributed to the sensory PC1, and all the peptides intervals except $\mathrm{D}$ and $\mathrm{G}$ determining the HPLC peptide mapping PC1 (table I). Significant correlations were found between adhesivity (sensory PC2) and the peptide intervals (peptide HPLC PC2) A, D, G, I, $\mathrm{L}$ (positive) and $\mathrm{K}$ (negative). As already mentioned, significant correlation was also found between adhesivity and smaller peptide $\mathrm{N}$.

HPLC peptide mapping was found to be very useful to predict sensory texture parameters (table IV). For each sensory variable, the PLS(1) method showed more than $75 \%$ variation explained by the HPLC peptides intervals.

Sensory texture versus free amino acids analysis: Principal components of sensory texture were highly correlated to those of free amino acid composition (table III. Amino acids related to young Appenzeller, asn, gln, GABA, and his were all negatively correlated to adhesivity whereas glu, AABA and val close to the older Appenzeller (figure 8 ) were positively correlated to 
adhesivity. These relations are suspected to be indirect since the kind of changes in amino acid composition referred to and the adhesivity were both shown to be strongly related to Appenzeller age. If some direct correlations were to be found between any specific amino acid composition and sensory texture parameters, this must be evaluated from an extended study.

\section{CONCLUSIONS}

This study is a contribution to the relational studies between sensory and instrumental data for the characterisation of cheese texture. Intensity of the correlations between principal components measured by a partial least square method (PLS) gave evidence that most of the sensory texture parameters, evaluated here by a trained panel, can be related to instrumental measurements obtained from harmonised methods. The study was limited to only two widely different cheese varieties thus extrapolation directly to other cheese varieties is not recommended. Results have clearly shown that relational studies could be improved with a combination of appropriate instrumental, sensory and statistical methods. Further studies should explore combination of different analytical measurements in order to reduce the number of explanatory variates and to predict sensory texture.

Among the instrumental groups of parameters studied here, the composition of free amino acids and peptide mapping were the most promising tools in term of predicting sensory texture. Any direct correlation between specific biochemical and sensory parameters must, however, be evaluated from an extended study. The gross composition data set appeared interestingly correlated to elasticity, whereas $\mathrm{N}$ fractionation gave more information on the firmness and adhesivity. Electrophoresis was found to be a poor method for the prediction of sensory texture parameters except maybe for adhesivity. The rheological information appeared equally or less correlated to sensory texture than most of the biochemical parameters. Deformability was found to be the sensory parameter least related to any of the instrumental data sets, but this was also the most difficult sensory parameter to evaluate even by trained assessors.

Interesting relations between sensory texture and the instrumental parameters were established from the results of this study. Firmness and friability were similarly related to most instrumental parameters, e.g., positive for strain at fracture, dry matter, and content of amino acid $\mathrm{N}$ and negative for modulus of deformability as well as for smaller, larger and hydrophobic peptides. Elasticity and deformability were also similarly correlated to instrumental parameters but almost always in the opposite direction as firmness and friability. Adhesivity was positively related to large amounts of small peptides suspected to be hydrophilic and also dry matter content, indicating that a cheese that contains less water than it is able to bind will be recognised as adhesive.

Even if the sensory and rheological methods used were previously harmonised, the participating laboratories have been involved in such a collaborative study for the first time. Thus, the research performed aimed to be exploratory. But finally, the approach described here can be considered as a guide for further relational studies on cheese.

\section{ACKNOWLEDGEMENTS}

The authors greatly acknowledge contribution by the following people: M. Zannoni and G. Panari from the Consorzio del Formaggio Parmigiano Reggiano (IT, Reggio Emilia), J. Hogenboom and P. Resmini from the Food Science and Technology Department (IT, University of Milan), E. Alichanidis and A. Michaelidou from the Laboratory of Dairy Technology (GR, University of Thessaloniki), M.O. Coquillard and D. Lefier from Inra - Station de recherches en technologie et analyses laitières (Poligny, France), U. Bütikofer and U. Moor 
from the Federal Dairy Research Institute (Liebefeld-Bern, Switzerland).

The authors acknowledge P. Schlich (Inra, Laboratoire des Arômes, France) to allow the use of a macro command developed with SAS software (SAS Institute Inc., Cary, NC, USA) to produce publication quality figures.

The work in BioSS was funded by the Scottish Office Agriculture, Environment and Fisheries Department and by the Swiss Federal Office for Education and Science.

The EC FLAIR 'SENS' (Concerted Action no. 0025 / COST 902) provided funds for travel and for meetings between partners.

\section{REFERENCES}

[1] AOAC Official Methods of Analysis ot the AOAC (1980) 13th edition. 16.241 Ash.

[2] AOAC Official Methods of Analysis of the AOAC (1980) 13th edition. 16.242 Total chloride.

[3] Addeo F., Chianese L., Sacchi R., Musso Spagna S., Ferranti P., Maloni A., Characterization of the oligopeptides of Parmigiano-Reggiano cheese soluble in $120 \mathrm{~g}$ trichloroacetic acid/L. J. Dairy Res. 61 (1994) 365-374.

[4] Andrews A.T., Proteinases in normal bovine milk and their action on caseins, J. Dairy Res. 50 (1983) 45-55.

[5] Ardö Y., Cheese fractionation methods for the evaluation of proteolysis in cheese, in: EC FLAIR SENS publication series 3 (4) 1994, pp. 35-40.

[6] Ardö Y., Barbosa M., Pochet S., Polychroniadou A., Comparison of two fractionation schemes for the evaluation of cheese proteolysis, in: Brief Communications Ealp, 24th International Dairy Congress, Melbourne, Australia, 1994, p. 98.

[7] Ardö Y., Gripon J.C., Comparative study of peptidolysis in some semi-hard round-eyed cheese varieties with different fat content, J. Dairy Sci. 62 (1995) 543-547.

[8] Arnold G.M., Williams A.A., The use of Generalised Procrustes Techniques Sensory Analysis, in: in: Piggott J.R. (ed.), Statistical Procedures in Food Research Elsevier Applied Science, London, 1986.

[9] Banks J.M., Hunter E.A., Muir D.D., Sensory properties of Cheddar cheese: effect of fat content on maturation, Milchwissenschaft 49 (1994) 9-12.

[10] Barlow I., Lloyd G.T., Ramshaw E.H., Miller A.J., McCabe G.P., McCabe L.,Correlations and changes in flavour and chemical parameters of Cheddar cheese during maturation, Austral J. Dairy Technol. 89 (1989) 7-18.
[11] Blakesley R.W., Boesi J.A., A new staining technique for protein in polyacrylamide gels using Coomassie brilliant blue G250, Anal. Biochem. 82 (1977) 580-582.

[12] Bosset J.O., Collomb M., Eberhard P., Grand M., Lavanchy P., Kaufmann E., Kreuter U., Application de méthodes d'analyse statistique univariée et multivariée à l'étude parallèle de critères chimiques, biochimiques, rhéologiques, microbiologiques et sensoriels du fromage d'emmental au moment de sa taxation, Partie I: Analyse de quelques profils de distribution, Chimia 46 (1992) 406-415.

[13] Bosset J.O., Collomb M., Eberhard P., Grand M., Lavanchy P., Kaufmann E., Kreuter U., Application de méthodes d'analyse statistique univariée et multivariée à l'étude parallèle de critères chimiques, biochimiques, rhéologiques, microbiologiques et sensoriels du fromage d'emmental au moment de sa taxation, Partie II: Analyse de corrélation, Lebensmwiss. Technol. 26 (1992) 111-116.

[14] Bütikofer U., Determination of free amino acids in standard solution, cheese and human plasma: Evaluation of FLAIR/COST 902 and FAM collaborative test, FAM Report, 1993, 1-28.

[15] Bütikofer U., Rüegg M., Ardö Y., Determination of nitrogen fractions in Cheese: evaluation of a collaborative study, Lebensm Wiss. Technol. 26 (1993) 271-275.

[16] Casiraghi E., Lucisano M., Pompei C., Correlation among instrumental texture, sensory texture and chemical composition of five Italian cheeses, Ital. J. Food Sci. 1 (1989) 53-63.

[17] Collomb M., Spahn M., Badestcher R.,Optimisation des conditions d'entreposage des échantillons de fromages à l'aide d'analyses chimiques, Schweiz Milchwirtsch. Forsch. 21 (1992) 6-11.

[18] Creamer L.K., Olson N.F., Rheological evaluation of maturing Cheddar cheese, J. Dairy Sci. 47 (1982) 631-636, 646 .

[19] de Jong L., The influence of the moisture content on the consistency and protein breakdown of cheese, Neth. Milk Dairy J. 32 (1978) 1-14.

[20] Eberhard P., Flückiger E., Puhan Z., Rheologische Eigenschaften ausgewählter Käsesorten. 2. Appenzeller und Tilsiter Käse, Schweiz Milchwirtsch. Forsch. 15 (1986) 97-102.

[21] Green M.L., Manning D.J., Development of texture and flavour in cheese and other fermented products, J. Dairy Res. 49 (1982) 737-748

[22] Heiss E., Essai de dosage de la matière grasse dans les fromages par des méthodes rapides, Deut. Molk. Ztg. 82 (1961) 67-70.

[23] IDF Standard 25, Protein content of processed cheese products, 1964.

[24] IDF Standard 4A, Cheese and processed cheese: determination of the total solids content (reference method), 1982. 
[25] Jack F.R., Piggott J.R., Paterson A., Relationships between electromyography, sensory and instrumental measures of Cheddar cheese texture, J. Food Sci. 58 (1993) 1313-1317.

[26] Krzanowski W.J., Principles of Multivariate Analysis. Oxford: Oxford Science publications, Clarendon Press, 1988.

[27] Lavanchy P., Bérodier F., Zannoni M., Noël Y., Adamo C., Squella J., Herrero L., L'Évaluation Sensorielle de la Texture des Fromages à Pâte Dure ou Semi-dure. Etude inter-laboratoires, Lebensm. Wiss. Technol. 26 (1993) 59-68

[28] Martens M., Martens H., Partial Least Squares Regression in Statistical Procedures in: Piggott J.R. (ed.), Food Research, Elsevier Applied Science, London, 1986.

[29] Molander E., Kristiansen K.R., Werner H., Instrumental and sensoric measurement of Brie texture, Milchwissenschaft 45 (1990) 589-593.

[30] Muir D.D., Hunter E.A., Sensory evaluation of cheddar cheese: Order of tasting and carryover effects, Food Quality Pref 3 (1991) 141-145.

[31] Noel Y., Zannoni M., Hunter E.A., Texture of Parmigiano Reggiano cheese: Statistical relationships between rheological and sensory variates, Lait 76 (1996) 243-254.

[32] Pearce K.N., The complexometric determination of calcium in dairy products, N. Z. J. Dairy Sci. Technol. 12 (1977) 113-115.

[33] Polychroniadou A., Objective indices of maturity of Feta and Teleme cheese, Milchwissenschaft 49 (1994) 376-379.

[34] Resmini P., Hogenboom J.A., Pazzaglia C., Pellegrino L., Free amino acids for the analytical characterization of Grana Padano cheese, Sci. Tec. Latt Casearia 44 (1993) 7-19.

[35] Rohm H., Lederer H., Ginzinger W., Relationship between rheological properties and composition of Swiss-type cheese. 1. Multiple regression analysis, Lebensm. Wiss. Technol. 25 (1992) 253-260.
[36] Rohm H., Lederer H., Ginzinger W., Relationship between rheological properties and composition of Swiss-type cheese. 2. Principal component regression, Milchwissenschaft 47 (1992) 620-623.

[37] Roudot-Algaron F., Le Bars D., Kerhoas L., Gripon J.C., Phosphopeptides from Comté cheese: Nature and origin, J. Food Sci. 59 (1994) 544-560.

[38] Rüegg M., Water in dairy products related to quality, with special reference to cheese, In: Simatos D., Multon J.L. (Eds), Properties of water in Foods, Martinus Nijhoff Publishers, Dordrecht, Netherlands, 1985, pp. 603-625.

[39] Szczesniak A.S., Correlations between objective and sensory texture measurements, Food Technol. 22 (1968) 981-985.

[40] Szczesniak A.S., Correlating sensory with instrumental texture measurements - An overview of recent developments, J. Texture Stud. 18 (1987) 1-15.

[41] van Vliet T., Inventory of test methods. Chap 3 , in: Rheological and fracture properties of cheese, Bull. Int. Dairy Fed. 268, 1991, pp. 16-25.

[42] Virgili R., Parolari G., Bolzoni L., Barbieri A., Mangia M., Careri S., Sagnoli S., Panari G., Zannoni M., Sensory-chemical relationships in Parmigiano-Reggiano cheese, Lebensm. Wiss. Technol. 27 (1994) 491-495.

[43] Williams A.A., Rogers C.A., Collons A.J., Relating chemical, physical and sensory data in food acceptance studies, Food Quality Pref. 1 (1988) 25-31.

[44] Zannoni M., Bertozzi L., Mora R., Indagine preliminare sulle caratteristiche sensoriali del Parmigiano-Reggiano: la struttura, Sci. Tec. Latt. Casearia 42 (1991) 192-202. 